УДК $612.35+612.357 .1$

\author{
Салах Атамнах \\ Свдокія Решетник \\ Юлія Левадянська \\ Василь Барановський \\ Станіслав Весельський \\ Петро Янчук
}

\title{
Вплив серотоніну на кон'югацію та гідроксилювання жовчних кислот у печінці щурів
}

У жовчі, отриманій у гострих дослідах на щурах-самцях із канюльованою жовчною протокою, виявлено стимулювальний вплив серотоніну на процеси кон'югації жовчних кислот і з таурином, і з гліцином. Блокада 5-HT 2 R кетансеріном призводила до зменшення коефіцієнта кон'югації холатів жовчі та усувала стимулювальний ефект серотоніну на кон'югацію ди- і тригідроксихоланових кислот з таурином і гліцином. У жовчі тварин не виявлено значних змін коефіцієнта гідроксилювання під впливом серотоніну як до, так і на фоні блокування 5- $\mathrm{HT}_{2} \mathrm{R}$ кетансеріном.

Ключові слова: серотонін, печінка, жовчні кислоти, кон’югація і гідроксилювання холатів.

Постановка наукової проблеми та її значення. Експресія серотонінових рецепторів на різних типах клітин печінки привертає увагу вчених до вивчення участі серотоніну в регуляції кровообігу, метаболізму, регенерації цього органу [1-5]. Порушення серотонінергічної регуляції функціонування печінки ведуть і безпосередньо до розвитку їі патологій, й обтяжують наслідки токсичних пошкоджень, сприяють канцерогенезу в іiі тканині [6; 7]. Одним із проявів гепатотропної регуляторної дії серотоніну є його здатність полегшувати перебіг холестатичних уражень печінки [8]. Серотонін також $\epsilon$ фактором, який регулює концентрацію у плазмі крові таких специфічних компонентів жовчі, як жовчні кислоти $[9 ; 10]$. Незважаючи на все, сказане вище, механізми дії серотоніну на процеси утворення і секреції окремих компонентів жовчі як показника, що відображає функціональний стан печінки, досі недостатньо вивчені. Дослідження ефектів аутокоїду на співвідношення різних холатів у жовчі важливі для виявлення ролі серотоніну в розвитку захворювань, пов'язаних зі зміною якісних властивостей печінкового секрету.

Мета роботи - дослідити якісні характеристики жовчі щурів шляхом розрахунку коефіцієнтів кон'югації і гідроксилювання холатів та співвідношення гліко- і таурокон'югатів жовчних кислот.

Матеріали і методи. Дослідження проведені на 26 білих лабораторних щурах-самцях вагою 180-250 г з дотриманням встановлених законом біоетичних норм. Для збору 10-хвилинних проб жовчі тваринам, які перебували під тіопенталовим наркозом (60 мг/кг маси тіла) проводили лапаротомію і канюлювали жовчну протоку. Через 30 хв після канюлювання жовчної протоки впродовж півгодини збирали жовч, у якій реєстрували вихідний рівень показників (ВР), після чого внутрішньопортально (в/п) вводили такі речовини: 1) фізіологічний розчин із розрахунку 1 мл/кг маси тіла (серія контроль, $\mathrm{n}=7)$; 2) серотонін у дозі 10 мкг/кг (серія серотонін, $\mathrm{n}=7$ ), 3) кетансерін (блокатор 5-НТ - $^{-}$ рецепторів) у дозі 3 мг/кг (серія кетансерін, $\mathrm{n}=6$ ). У групі «кетансерін + серотонін» $(\mathrm{n}=6)$ блокатор вводили після вимірювання вихідного рівня в тій самій дозі, що й у серії кетансерін, а серотонін (10 мкг/кг) через півгодини після введення блокатора. Збір півгодинних проб жовчі тривав три години. В отриманих шести 30-хвилинних пробах визначали концентрацію жовчних кислот за методом Весельського та співавторів [11]. Після чого розраховували коефіцієнт кон'югації (КК - співвідношення кон'югованих холатів до вільних), коефіцієнт гідроксилювання (КГ - співвідношення тригідроксихоланових кислот до дигідроксихоланових), а також співвідношення гліко- і таурокон'югатів жовчних кислот (Г/Т-коефіцієнт). Статистичну обробку даних проводили з використанням пакету Statistica 7.0 (Stat Soft, США). Результати подані у вигляді медіани та верхнього і нижнього квартилів (Me [Q25; Q75]). Статистично значущими вважали відмінності прир < 0,05.

Виклад основного матеріалу та обгрунтування отриманих результатів дослідження. У серії контрольних дослідівз в/п введенням фізіологічного розчину вірогідних змін КК щодо ВР не виявлено. Під впливом серотоніну вже у першій, зібраній після введення аутокоїду, півгодинній пробі жовчі спостерігалося збільшення КК, яке зберігалося упродовж усього досліду з максимальним ефектом у четвертій пробі (підвищення на 48,7 \% щодо ВР; $\mathrm{p}<0,05$ ) (табл. 1). Тобто під впливом серотоніну 
відбувалося посилення процесів біотрансформації жовчних кислот через їх кон'югацію, а також стимулювалося їх вилучення з крові, що надходить по ворітних судинах від кишечника.

Блокада 5-НТ 2-рецепторів за допомогою кетансеріну призводила до зниження КК у другій пробі жовчі на $15,3 \%$ ( < 0,05$)$ з подальшим поверненням цього показника до вихідного значення. При введенні серотоніну на фоні блокади $5-\mathrm{HT}_{2} \mathrm{R}$ кетансеріном не відбувалося зростання КК, значення якого були близькими до ВР (табл. 1).

3 огляду на отримані в дослідженні значення КГ можна припустити, що на відміну від процесів кон'югації холатів, значних і тривалих ефектів серотоніну на гідроксилювання жовчних кислот не виявлено. Процеси гідроксилювання жовчних кислот у гепатоцитах щурів не зазнавали значних змін і при блокаді серотонінових рецепторів кетансеріном та при дії екзогенного серотоніну та фоні кетансеріну (табл. 1.).

Таблиця 1

Співвідношення холатів у жовчі щурів (мг, \%) при дії серотоніну (10 мкг/кг) в умовах блокади 5-HT 2 Rкетансеріном (3 мг/кг) (Ме [Q25; Q75]; $\mathbf{n}=26)$

\begin{tabular}{|c|c|c|c|c|}
\hline $\begin{array}{c}\text { № } \\
\text { проби }\end{array}$ & $\begin{array}{c}\text { Серія } \\
\text { Дослідів }\end{array}$ & $\begin{array}{l}\text { Коефіціснт } \\
\text { кон'югації }\end{array}$ & $\begin{array}{l}\text { Коефіціснт } \\
\text { гідроксилювання }\end{array}$ & $\begin{array}{c}\text { Співвідношення гліко- i } \\
\text { таурокон'югатів жовчних } \\
\text { кислот }\end{array}$ \\
\hline \multirow{5}{*}{1} & \multicolumn{4}{|c|}{ Вихідний рівень } \\
\hline & Контроль & $16,2[12,9 ; 20,4]$ & $2,6[2,4 ; 2,7]$ & $0,6[0,5 ; 0,6]$ \\
\hline & Серотонін & $11,7[9,7 ; 13,0]$ & $2,7[2,5 ; 2,7]$ & $0,7[0,6 ; 0,7]$ \\
\hline & Кетансерін & $13,1[10,9 ; 18,1]$ & $2,6[2,5 ; 2,7]$ & $0,7[0,6 ; 0,7]$ \\
\hline & Кетансерін +Серотонін & $14,5[10,1 ; 18,2]$ & $2,7[2,6 ; 2,8]$ & $0,7[0,6 ; 0,7]$ \\
\hline \multirow{5}{*}{2} & \multicolumn{4}{|c|}{$\begin{array}{c}\text { Внутрішньопортальне введення серотоніну (серія Серотонін), кетансеріну (серія Кетансерін) та } \\
\text { кетансеріну і серотоніну (серія Кетансерін+Серотонін) }\end{array}$} \\
\hline & Контроль & $15,8[13,1 ; 20,4]$ & $2,5[2,4 ; 2,7]$ & $0,6[0,5 ; 0,6]$ \\
\hline & Серотонін & $15,3[12,5 ; 18,1]^{*}$ & $2,7[2,6 ; 2,8]$ & $0,7[0,6 ; 0,7]$ \\
\hline & Кетансерін & $11,1[9,4 ; 16,1]^{*}$ & $2,6[2,6 ; 2,7]$ & $0,7[0,6 ; 0,7]$ \\
\hline & Кетансерін+Серотонін & $11,3[8,7 ; 14,0]^{*}$ & $2,9[2,8 ; 2,9]$ & $0,7[0,6 ; 0,8]$ \\
\hline \multirow{5}{*}{3} & \multicolumn{4}{|c|}{ Внутрішньопортальне введення серотоніну (серія Кетансерін+Серотонін) } \\
\hline & Контроль & $16,8[12,8 ; 20,1]$ & $2,5[2,4 ; 2,8]$ & $0,6[0,5 ; 0,6]$ \\
\hline & Серотонін & $16,1[11,9 ; 19,3]^{*}$ & $2,6[2,3 ; 2,7]$ & $0,6[0,6 ; 0,7]$ \\
\hline & Кетансерін & $12,7[9,9 ; 17,5]$ & $2,7[2,6 ; 2,7]$ & $0,7[0,6 ; 0,7]$ \\
\hline & Кетансерін+Серотонін & $13,5[10,3 ; 17,5]$ & $2,8[2,7 ; 2,9]$ & $0,7[0,6 ; 0,8]$ \\
\hline \multirow{4}{*}{4} & Контроль & $16,8[12,6 ; 19,7]$ & $2,7[2,5 ; 2,7]$ & $0,6[0,5 ; 0,6]$ \\
\hline & Серотонін & $17,4[14,0 ; 20,9]^{*}$ & $2,7[2,6 ; 2,8]$ & $0,6[0,6 ; 0,7]$ \\
\hline & Кетансерін & $13,5[11,2 ; 19,0]$ & $2,6[2,5 ; 2,7]$ & $0,7[0,7 ; 0,7]$ \\
\hline & Кетансерін+Серотонін & $14,9[11,9 ; 19,3]$ & $2,8[2,6 ; 2,9]$ & $0,7[0,6 ; 0,8]$ \\
\hline \multirow{4}{*}{5} & Контроль & $16,9[12,2 ; 17,9]$ & $2,5[2,4 ; 2,7]$ & $0,5[0,5 ; 0,6]$ \\
\hline & Серотонін & $15,4[13,3 ; 18,1]^{*}$ & $2,7[2,6 ; 2,8]$ & $0,6[0,6 ; 0,7]$ \\
\hline & Кетансерін & $13,0[12,3 ; 20,2]$ & $2,7[2,5 ; 2,8]$ & $0,7[0,7 ; 0,7]$ \\
\hline & Кетансерін+Серотонін & $14,2[10,5 ; 17,9]$ & $2,7[2,7 ; 2,8]$ & $0,7[0,6 ; 0,7]$ \\
\hline \multirow{4}{*}{6} & Контроль & $16,5[12,1 ; 17,1]$ & $2,6[2,5 ; 2,8]$ & $0,6[0,5 ; 0,6]$ \\
\hline & Серотонін & $13,0[10,4 ; 14,9]^{*}$ & $2,7[2,4 ; 2,8]$ & $0,6[0,5 ; 0,6]^{*}$ \\
\hline & Кетансерін & $13,0[10,2 ; 20,4]$ & $2,7[2,6 ; 2,8]$ & $0,7[0,6 ; 0,7]$ \\
\hline & Кетансерін+ Серотонін & $13,2[10,0 ; 17,9]$ & $2,8[2,7 ; 2,8]$ & $0,7[0,6 ; 0,8]$ \\
\hline
\end{tabular}

Примітка: * - p $<0,05$ порівняно із вихідним рівнем (ВР - значення коефіцієнтів, визначених за концентраціями жовчної кислоти у першій півгодинній пробі жовчі, отриманій до введення застосованих сполук).

У співвідношенні глікокон'югатів і таурокон'югатів жовчних кислот вірогідне зменшення показника виявлене тільки в останній півгодинній пробі жовчі, отриманій через 2,5 години після введення кетансеріну. При цьому у всіх інших експериментальних серіях Г/Т коефіцієнт жовчі щурів лишався близьким до ВР (табл. 1).

Таким чином, найбільш істотні зміни виявлені для КК, що є одним із інтегративних показників злагодженості функціонування систем метаболічних перетворень і транспорту холатів передусім у 
гепатоцитах. У цілому такий показник, як КК надає інформацію про солюбілізаційні властивості жовчі, а співвідношення вільних і кон'югованих фракцій холатів є одним із критеріїв оцінки літогенності жовчі.Порушення біосинтезу жовчних кислот, у тому числі їх кон'югації, наприклад, внаслідок вроджених метаболічних дефектів, призводить до важких наслідків для здоров'я і життя [12; 13]. Кон'югація вільних холатів з таурином і гліцином - останній етап у біосинтезі первинних та біотрансформації вториннихжовчних кислот і ії фізіологічний зміст полягає у забезпеченні більш високої міцелярної концентрації холатів у порожнині кишечника, що, у свою чергу, сприяє поліпшенню абсорбції ліпідів і жиророзчинних вітамінів [13]. Патологічні порушення утворення кон'югованих із таурином і гліцином холатів стають причиною малабсорбції жиророзчинних вітамінів $\mathrm{i}$ холестатичних уражень печінки [14] та вимагають подальших досліджень механізмів регуляції метаболічних перетворень холестеролу і жовчних кислот.

Висновки та перспективи подальшого дослідження. Серотонін (10 мкг/кг) при внутрішньопортальному введенні посилює кон'югацію жовчних кислот у печінці щурів і 3 таурином, i 3 гліцином. Блокада 5- $\mathrm{HT}_{2} \mathrm{R}$ кетансеріном (3 мг/кг) призводить до зменшення коефіцієнта кон'югації холатів жовчі та усуває стимулювальний ефект серотоніну на кон'югацію ди- і тригідроксихоланових кислот з таурином і гліцином. Коефіцієнт гідроксилювання у жовчі тварин під впливом серотоніну не змінюється i до, $\mathrm{i}$ на фоні блокування 5- $\mathrm{HT}_{2} \mathrm{R}$ кетансеріном.

\section{Джерела та література}

1. Mann D. A. Serotonin paracrine signaling in tissue fibrosis / D. A. Mann, F. Oakley // Biochimica et Biophysica Acta. - 2013. - Vol. 1832, № 7. - P. 905-1010.

2. Stimulating healthy tissue regeneration by targeting the $5-\mathrm{HT}_{2 \mathrm{~B}}$ receptor in chronic liver disease / Ebrahimkhani M. R., Oakley F., Murphy L. B. [et al.] // Nat Med. - 2011. - Vol. 17, № 12. - P. 1668-1673.

3. The emerging role of serotonin in liver regeneration / G. K. Papadimasa, K. N. Tzirogiannisa, M. G. Mykoniatisa [et al.] // Swiss Medical Weekly. - 2012. - Vol. 142, № 4. - P. 135-148.

4. Ruddell R. G. The function of serotonin within the liver / R. G. Ruddell, D. A. Mann, G. A. Ramm // J Hepatol. 2008. - 48, №4. - P.666-675.

5. Effect of 5-HT 7 receptor blockade on liver regeneration after 60-70\% partial hepatectomy / K. N. Tzirogiannis, K. T. Kourentzi, S. Zyg [et al.] // BMC Gastroenterology. - 2014. - 14: 201. doi:10.1186/s12876-014-0201-2.

6. Serotonin deficiency exacerbates acetaminophen-induced liver toxicity in mice / Zhang J., Song S., Pang Q. [et al.] // Sci Rep. - 2015. - 5:8098. doi: 10.1038/srep08098.

7. Serotonin promotes tumor growth in human hepatocellular cancer / Soll C., Jang J. H., Riener M. O. [et al.] // Hepatology. - 2010. - Vol. 51, №4. - P. 1244-1254.

8. Serotonin protects mouse liver from cholestatic injuryby decreasing bile salt pool after bile duct ligation / Jang J.-H., Rickenbacher A., Humar B. [et al.] // Hepatology. - 2012. - Vol. 56, Issue 1. - P. $209-218$.

9. Peripheral serotonin enhances lipid metabolism by accelerating bile acid turnover / Watanabe H., Akasaka D., Ogasawara H. [et al.] // Endocrinology. - 2010. - Vol. 151, № 10. - P. 4776-4786.

10. Effect of peripheral 5-HT on glucose and lipid metabolism in wether sheep / Watanabe H., Saito R., Nakano T. [et al.] // PLoS One. - 2014. - Vol.9, № 2. - P.880-892.

11.А.c. 4411066/14 СССР, МБИ G 01 N33/50. Способ определения желчных кислот в биологических гидкостях / С. П. Весельский, П. С. Лященко, И. А. Лукьяненко (СССР). - № 1624322; Заявл. 25.01.1988; Опубл. 30.01.1991, Бюл. № 4.

12. Genetic defects in bile acid conjugation cause fat-soluble vitamin deficiency / Setchell K. D., Heubi J. E., Shah S. [et al.] // Gastroenterology. - 2013. - Vol. 144, № 5. - P. 945-955.

13. Clayton P. T. Disorders of bile acid synthesis // J Inherit Metab Dis. - 2011. - Vol. 34, № 3. - P. 593-604.

14. Treatment of bile acid amidation defects with glycocholic acid / Heubi J. E., Setchell K. D., Jha P. // Hepatology. - 2015. - Vol. 61, № 1. - P. 268-274.

Атамнах Салах, Решетник Евдокия, Левадянська Ю., Барановский Василий, Весельский Станислав, Янчук Петр. Влияние серотонина на конъюгации и гидроксилирования желчных кислот в печени крыс. В желчи, полученной в острых опытах на крысах-самцах с канюльованою желчным протоком, обнаружено стимулирующее влияние серотонина на процессы конъюгации желчных кислот и с таурином, и с глицином. Блокада 5-HT2R кетансерин приводила к уменьшению коэффициента конъюгации холатов желчи и устраняла стимулирующий эффект серотонина на конъюгации ди- и тригидроксихоланових кислот с таурином и глицином. В желчи животных не выявлено значительных изменений коэффициента гидроксилирования под влиянием серотонина как до, так и на фоне блокирования 5-HT2R кетансерин.

Ключевые слова: серотонин, печень, желчные кислоты, конъюгация и гидроксилирования холатов. 
Athamnah Salah, Reshetnik Evdokiya, Levadianska J., Baranovsky Vasul, Veselsky Stanislav, Yanchuk Petro. Serotonin Effects on Conjugation and Hydroxylation of Bile Acid in the Rats Liver. In acute experiments on male rats with cannulated bile duct it was revealed stimulating effect of serotonin on the conjugation of bile acids with taurine as well as with glycine.Ketanserin blockade of 5-HT2R leads to the inhibition cholates conjugation with taurine and glycine and eliminates serotonin stimulating effects on bile acid conjugations in rat liver. In the rat bile not were found significant variations of hydroxylation under the influence of serotonin as well as on the background in ketanserin blocking 5-HT2R.

Key words: serotonin, liver, bile acid,cholates conjugation and hydroxylation.

Стаття надійшла до редколегії $21.01 .2015 \mathrm{p}$.

УДК 612.172-055.25

\section{Ігор Коцан \\ Тетяна Качинська \\ Світлана Берлач}

\section{Особливості варіабельності серцевого ритму в дівчат підліткового періодуз різним рівнемвегетативної регуляції}

Статтю присвячено вивченню особливостей стану серцево-судинноїсистеми в осібжіночої статі з різним рівнем вегетативної регуляції. В період пубертатуметодамистатистичного, спектрального та часового аналізу виявлено збільшення впливу симпатичного рівнярегуляції на роботу серця під час виконання розумових та фізичних завдань.

Ключові слова: варіативність серцевого ритму, парасимпатичний рівень вегетативної регуляції, симпатичний рівень вегетативної регуляції.

Постановка наукової проблеми та їі значення. Підлітковий вік, будучи одним 3 критичних періодів онтогенезу, характеризується напруженням нейроендокринних і гормональних механізмів регуляції $[5$, с. 83 ; 6, с. 28 ; 14, с. 421-424]. Посилений ріст, підвищена рухова й нервово-психічна активність приводять до значної напруги в роботі нервової системи (особливо вегетативної нервової системи), ендокринних залоз і обміну речовин. Організм підлітків через незавершеність морфофункціонального розвитку, недосконалість його регуляторних механізмів, високу лабільність, гостро реагує на впливи несприятливих факторів [7, с. 164-166; 14, с. 422].

Варіабельність серцевого ритму (ВСР) є універсальною фізіологічною властивістю, яка не тільки відображає стан вегетативної нервової системи, а й є показником регуляторних процесів на рівні цілісного організму, відображає стан його адаптаційних резервів і резервів здоров’я [1, с. 10; 2 , c. 50; 4]. ВСР дає змогу виявити особливості регуляторних механізмів серця при фізичних та розумових навантаженнях в осіб із різними типами гемодинаміки, а також відображає особливості статевого розвитку. Вивчення механізмів нейроендокринної регуляції при різних стадіях статевого дозрівання має велике значення для прогностичної оцінки адаптаційних можливостей організму підлітків [8, с. $200 ; 9$, с. $54 ; 11]$.

Аналіз досліджень цієї теми. Значна кількість досліджень ВСР проведена як в країнах СНД $[1$, с. $10 ; 2$, с. $10 ; 4]$, так і за їі межами $[12$, с. $374 ; 13$, с. $611 ; 14]$. За результатами деяких із них встановлено, що ВСР певною мірою є генетично детермінованою [4, с. 76; 8]. Водночас виявлено значні індивідуальні розбіжності в їі параметрах у здорових осіб. 3 одного боку, це пояснюється потребою враховувати низку важливих чинників, таких як: вік, стать, психосоціальні фактори, рівень рухової активності, вага тіла, які позначаються на показниках ВСР. 3 іншого боку, суттєва індивідуальна варіативність значень ВСР, очевидно, зумовлена індивідуально-типологічними особливостями організму людини [4, с. 70-85; 14].

(C) Коцан I., Качинська Т., Берлач С., 2015 